\title{
陽極酸化アルミナ層を担体とした 白金/アルミナプレート状触媒の触媒有効係数
}

\author{
村 田究*, 亀 山秀 雄*
}

\author{
Effectiveness Factor of Pt/Alumina Plate Type Catalysts \\ Using Anodized Alumina Layer as Catalyst Support
}

Kyu MURATA* and Hideo KAMEYAMA*

\begin{abstract}
The effectiveness factor of $\mathrm{Pt} / \mathrm{Al}_{2} \mathrm{O}_{3} / \mathrm{Al}$ plate catalyst was studied experimentally. The $\mathrm{Pt} / \mathrm{Al}_{2} \mathrm{O}_{3}$ catalyst layer, prepared by anodic oxidation and hot-water treatment, had a porous structure and a narrow pore-size distribution. Catalyst porosity was about 0.5 and the mean pore radius about $2 \mathrm{~nm}$. The rate of cyclohexane dehydrogenation reaction increased with the thickness of $\mathrm{Pt} / \mathrm{Al}_{2} \mathrm{O}_{3}$ catalyst layer to a certain peak, then the effectiveness factor decreased with thickness. This was because reactant diffusion into the catalyst layer was the controlling step. The observed reaction rate per apparent surface area is governed by the effective diffusion coefficient and the reaction rate constant. The reaction rate constant can be improved by augmenting the Pt content and Pt dispersion. The effective diffusion coefficient will be also improved with a large pore radius, which can be realized by controlling the anodized alumina layer pore structure.
\end{abstract}

Key Words : Plate Type Catalyst, Effectiveness Factor, Anodic Oxidation, Pt/Alumina Catalyst, Pore Structure

\section{1. 緒言}

アルミニゥム金属上に形成した陽極酸化アルミナ層を 触媒化することでプレート状触媒が調製できる ${ }^{3)}$ 。この プレート状触媒は伝熱性が高く, 反応器と熱交換器の機 能をあわせ持つ熱交換型反応器が可能になる。

一方, 触媒反応において反応物質は触媒外表面から細 孔内部一拡散し触媒層表面と内部で反応が進行する。触 媒層内部では反応による反応物質の消失之拡散抵抗によ り反応物質濃度が低下するために内部に担持された触媒 種は外表面ほど有効に反応に使われない。したがって担 持した触媒種が反応によ゙のくらい有效に使われているの かを示す触媒有効係数は触媒設計の上で重要な因子にな り有効係数を大きくするよう触媒担体を設計する必要が ある。

理論的には様々な形状を持つ触媒について触媒有効係 数が導出できるが，実際には実験によって触媒層の構造 や反応速度定数を明らかにする必要がある。

本論文では陽極酸化アルミナ層を触媒担体としたプレー 卜状触媒の触媒有効係数を検討した。シクロヘキサン脱 水素反応をモデル反応として有効拡散係数を算出した。 触媒活性を上げるためには陽極酸化条件, 熱水処理条件 による細孔構造の制御が必要であることを示した。

* 東京農工大学 工学部（干184 東京都小金井市中町2-24-16） Dept. of Chem. Eng., Tokyo Univ. of Agriculture and Tech. (24-16, Nakamachi 2-chome, Koganei-shi, Tokyo 184)

\section{2. プレート状触媒の触媒有効係数の導出}

\section{1 触媒有効係数}

触媒表面から深さ方向 $(l)$ におけるシクロヘキサン濃 度 $\left(C_{C}\right)$ の経持 $(t)$ 変化は以下の式で表わせる。

$$
\frac{\partial C_{c}}{\partial t}=D\left(\frac{\partial^{2} C_{c}}{\partial l^{2}}\right)-r_{V}
$$

ここで $D$ は有効拡散係数, $r_{V}$ は体積あたりの反応速度 定数である。触媒層内の温度分布は $0.1 \mathrm{~K}$ 以内である之 試算されており ${ }^{4)}$, 触媒層の温度は均一であると考えら れる。シクロヘキサン脱水素反応 $\left(r_{V}\right)$ はシクロへキサ ンの濃度に比例するので ${ }^{3)}$ 以下の式が得られる。

$$
r_{v}=k \cdot C_{C}
$$

定常状態ではシクロヘキサン濃度变化はないので式 (1) の左辺は 0 である。式 (1) と式 (2) より以下の微分式 が得られる。

$$
D\left[\frac{\partial^{2} C_{C}}{\partial l^{2}}\right]=k \cdot C_{C}
$$

境界条件は以下の式で表わせられる。

$$
\begin{aligned}
& l=O: C_{c}=C_{C}^{\circ} \\
& l=L: \frac{d C_{C}}{d L}=O
\end{aligned}
$$

式 (3) の解は

$$
\begin{aligned}
\frac{C_{C}}{C_{C}^{\circ}} & =\frac{\cosh \phi(1-l / L)}{\cosh \phi} \\
\because \phi & =L \sqrt{\frac{k}{D}} \cdots \cdots \cdots \cdots \cdots \cdots \cdots \cdots
\end{aligned}
$$


ここでфはThiele numberである。Thiele number が小さければ触媒層内の濃度分布変化は小さく触媒有効 係数が 1 に近づくことを表わす。

触媒層がとてあ薄い場合には，すべての触媒種が反応 ガス流体と外表面で接するので有効係数は 1 になる。こ の時に見かけ面積当たりの反応速度は最大值 $\left(r_{\text {SMAX }}\right)$ を示し以下のように表わせられる。

$r_{S M A X}=k \cdot C_{C}^{\circ} \cdot L$

定常状態では見かけ面積当たりの反応速度 $\left(r_{s}\right)$ は触 媒表面における拡散速度であるので以下の式になる。

$$
r_{s}=-D \cdot\left(\frac{\partial C_{c}}{\partial l}\right]_{l=o} \ldots
$$

解は,

$$
r_{s}=D \cdot C_{c}^{\circ} \cdot \sqrt{\frac{k}{D}} \cdot \tanh \phi
$$

触媒有効係数 $(\eta)$ は式 (10)を式 (8) で除したものであ る。

$$
\eta=\frac{r_{\mathrm{s}}}{r_{\text {SMAX }}}=\frac{\tanh \phi}{\phi}
$$

\section{2 実験による触媒有効係数の算出}

実験で得られる見かけの反応速度定数 $(n \cdot k)$ は拡 散の影響を含み真の反応速度定数に有効係数をかけた值 で表現される。Weisz 数は見かけの反応速度定数の項 を含む無次元数である。実験結果と式 (12)よりWeisz 数 を算出し式 (13) から Thiele 数を算出し触媒有効係数を 求めた。

$$
W_{\mathrm{s}}=\phi^{2} \cdot \eta=\left[L \cdot \sqrt{\frac{k}{D}}\right]^{2} \cdot \eta=(\eta \cdot k) \frac{L^{2}}{D}
$$

$W_{s}=\phi^{2} \cdot \eta=\phi \cdot \tanh \phi$ $\cdot(13)$

\section{3. 実験方法}

\section{1 プレート状触媒の調製 5)}

$\mathrm{Pt} / \mathrm{Al}_{2} \mathrm{O}_{3} / \mathrm{Al}$ プレート状触媒を調製した。本章で用 いた触媒の分析結果を表 1 に示した。

\section{陽極酸化法}

市販のアルミニウム板（JIS A-1050，純度約99.5\%） を用いた。酸とアルカリで洗浄した後に283-298K の一 定温度に保った $4 \mathrm{wt} \%$ のュウ酸水溶液にアルミニウ ムを陽極に，ステンレスを陰極に電流密度 $50 \mathrm{~A} / \mathrm{m}^{2}$ で 通電しアルミナ層を形成した。

\section{熱水処理法}

陽極酸化した基盤に熱水処理を施しアルミナ中に白金 を担持した。塩化白金酸水溶液（1g-Pt/l）をアンモ二 ア水で $\mathrm{pH} 11.4$ に調整し $353 \mathrm{~K}$ に昇温した中に最大 $6 \mathrm{~h}$ 含浸した。熱水処理後に塩化カリウム水溶液 $(0.3 \mathrm{wt} \%)$ に20分含浸, 十分に水洗し乾燥後, 焼成 $(623 \mathrm{~K}, 1 \mathrm{~h})$ して触媒とした。
Table 1 Physical properties of prepared catalysts.

\begin{tabular}{c|c|c|c|c}
\hline \multirow{2}{*}{ Sample } & \multirow{2}{*}{$\begin{array}{c}\text { Thickness of catalyst } \\
\text { layer }[\mu \mathrm{m}]\end{array}$} & \multicolumn{2}{|c|}{ Pt contents } & Pt dispersion \\
\cline { 3 - 4 } & {$\left[\mathrm{g} / \mathrm{m}^{2}\right]$} & {$[\mathrm{wt} \%]$} & {$[-]$} \\
\hline $\mathrm{A}$ & 9 & 1.1 & - & 0.51 \\
\hline $\mathrm{B}$ & 15 & 1.9 & - & 0.44 \\
\hline $\mathrm{C}$ & 27 & 2.9 & 7.2 & 0.47 \\
\hline $\mathrm{D}$ & 50 & 5.7 & 8.9 & 0.53 \\
\hline $\mathrm{E}$ & 80 & 11.1 & 10.2 & 0.48 \\
\hline $\mathrm{F}$ & 175 & 13.41 & 7.9 & 0.59 \\
\hline $\mathrm{G}$ & 195 & 15.84 & 8.0 & 0.47 \\
\hline
\end{tabular}

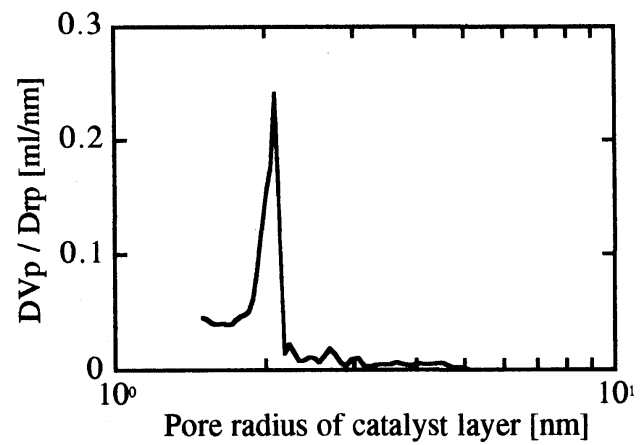

Fig. 1 Pore size distribution of the plate type catalyst.

\section{2 分析方法 ${ }^{5)}$}

白金/アルミナ触媒層の細孔分布を窒素吸着法により Dollimore 法 ${ }^{1)}$ から計算した。触媒層厚みは触媒断面 の EPMA分析により測定した。白金担持量は原子吸光 法（Shimazu AA-680）により測定した。白金分散度 は COパルス法 ${ }^{7)}$ により求めた。分析結果を表 1 に示し た。

\section{3 触媒活性の測定 ${ }^{5)}$}

調製した触媒の活性評価はシクロヘキサン脱水素反応 により行った。反応温度 $473 \mathrm{~K}$, シクロヘキサンを窒素 で希釈しシクロヘキサン分圧 $9 \mathrm{kPa}$ で反応試験を行っ た。反応管入り口，出口のガスを FID ガスクロマトグ ラフ（Shimazu GC-8A）で分析し反応速度を算出し た。

\section{4. 結果と考察}

\section{1 プレート触媒の有効拡散係数}

4. 1.1 触媒層の細孔径分布

図 1 はプレート触媒の典型的な細孔分布を測定した あのである。本触媒は狭い細孔分布を持ち平均半径は $2 \mathrm{~nm}$ であった。プレート触媒の細孔分布は熱水処理条 件で決定されることが報告されているが ${ }^{6)}$ 本条件では熱 水処理条件を $353 \mathrm{~K}, 6 \mathrm{~h}$ と一定にしているためによ゙の 


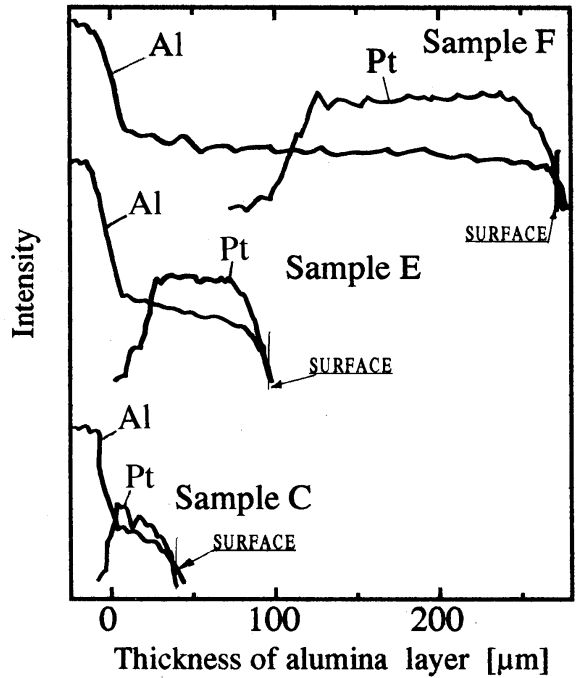

Fig. 2 EPMA patterns of cross section of the plate type catalysts, $\mathrm{C}, \mathrm{E}$ and $\mathrm{F}$.

触媒も同じ細孔分布を持つ。

4. 1. 2 細孔内拡散係数

本触媒の細孔半径は $2 \mathrm{~nm}$ でありシクロヘキサン分圧 が $9 \mathrm{kPa}$ と小さいことから触媒層へはクヌーセン拡散 により反応分子が移動すると考えた ${ }^{8)}$ 。細孔内拡散係数 $\left(D_{N}\right)$ は以下の式で表現される。

$$
\begin{gathered}
D_{N}=3.067 \cdot r_{\mathrm{e}} \cdot \sqrt{\frac{T}{M}}=4.60 \times 10^{-7} \mathrm{~m}^{2} / \mathrm{s} \\
\because T=473 \mathrm{~K}, \quad M=0.084 \mathrm{~kg} / \mathrm{mol} \\
r_{e}=20 \times 10^{-10} \mathrm{~m}
\end{gathered}
$$

\section{1.3 有効拡散係数}

触媒層の有効拡散係数は簡単で実用的な並列細孔モデ ル2゙を用いた。このモデルでは均一な半径と長さを持っ た多数の細孔が並列に配列して細孔群を形成している。 ただし細孔は屈曲しており, 拡散長さ $(L e)$ は触媒層厚 み $(L)$ よりあ長いと考える。拡散長さの度合いを屈曲 係数 $(\tau)$ として評価し以下のように表わす。

$$
\tau=(L e / L)^{2}
$$

通常の触媒は $\tau=2 \sim 4$ であり ${ }^{8)}$ 本触媒では $\tau=3$ と仮 定した。また本プレート触媒の空隙率は $0.4 \sim 0.6$ であり 0.5 とした。有効拡散係数は以下のようになる。

$$
\begin{gathered}
D=\frac{\varepsilon}{\tau} \cdot D_{N}=7.67 \cdot 10^{-8} \mathrm{~m}^{2} / \mathrm{s} \\
\because \varepsilon=0.5, \quad \tau=3
\end{gathered}
$$

\section{2 触媒層厚みと活性}

4. 2. 1 触媒層厚み

図 2 は触媒 $\mathrm{C}, \mathrm{E}, \mathrm{F}$ の触媒層断面の EPMA 分析結

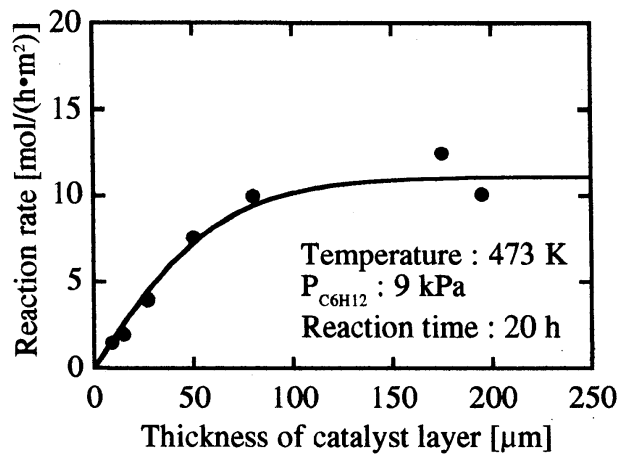

Fig. 3 Effect of thickness of the catalyst layer on catalytic ractivity.

Table 2 The $k, k$, Ws, $\phi$ and $\eta$ of each prepared catalysts.

\begin{tabular}{c|c|c|c|c|c}
\hline Sample & $\begin{array}{c}k^{\prime}(=\eta \cdot k) \\
{[1 / \mathrm{s}]}\end{array}$ & $\begin{array}{c}W s \\
{[-]}\end{array}$ & $\begin{array}{c}\phi \\
{[-]}\end{array}$ & $\begin{array}{c}k \\
{[1 / \mathrm{s}]}\end{array}$ & $\begin{array}{c}\eta \\
{[-]}\end{array}$ \\
\hline $\mathrm{A}$ & 16.15 & 0.05 & 0.23 & 16.5 & 0.98 \\
\hline $\mathrm{B}$ & 12.80 & 0.06 & 0.24 & 14.2 & 0.90 \\
\hline $\mathrm{C}$ & 12.77 & 0.13 & 0.36 & 14.8 & 0.86 \\
\hline $\mathrm{D}$ & 12.59 & 0.69 & 0.94 & 16.1 & 0.78 \\
\hline $\mathrm{E}$ & 14.40 & 1.05 & 1.24 & 21.2 & 0.68 \\
\hline $\mathrm{F}$ & 7.78 & 3.04 & 3.05 & 23.6 & 0.33 \\
\hline $\mathrm{G}$ & 5.92 & 2.55 & 2.59 & 19.7 & 0.30 \\
\hline
\end{tabular}

果を示している。X軸は触媒担体層底部からの厚み方向 を示しY軸はそれぞれの元素の強度を示している。白 金/アルミナ触媒層はアルミニゥムと白金がとあにピー クを示す範囲である。表 1 に触媒層厚みを示した。白金 のX線強度はアルミナ層表面から深さ方向でほぼ等し い強度を示すことから白金はアルミナ首に均一に担持し ていると考えられる。

4. 2.2 アルミニウムあたりの白金担持量

アルミナ重量あたりの白金担持量を触媒首厚み, アル ミナ密度, 面積あたりの白金担持量より計算し表 1 に示 した。どの触媒むアルミナあたりの白金担持量は 7 10wt\%であった。

4. 2.3 触媒層厚みと活性

図 3 には白金/アルミナ触媒層厚みとシクロヘキサン 脱水素活性触媒活性との関係を示している。触媒層厚み が $80 \mu \mathrm{m}$ までは触媒活性は触媒首に比例して向上したが それ以上の厚みでは触媒活性はほぼ横這いになった。

\section{3 プレート触媒の有効係数}

見かけの反応速度定数 $\left(k^{\prime}\right)$ と式 (12) (13) から Weisz 数 を計算し Thiele 数を算出した。表 2 にはそれぞれの触 媒の $k$ ', Ws, $\phi, k$ と $\eta$ を示した。

図 4 は触媒層厚みに伴う触媒有効係数の变化を示して 


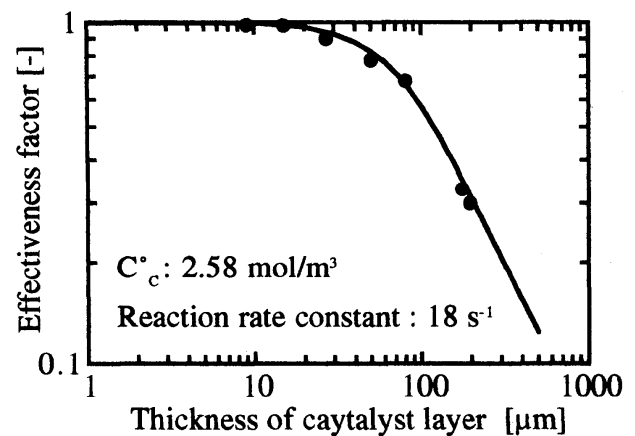

Fig. 4 Relationship between thickness of catalyst layer and effectiveness factor.

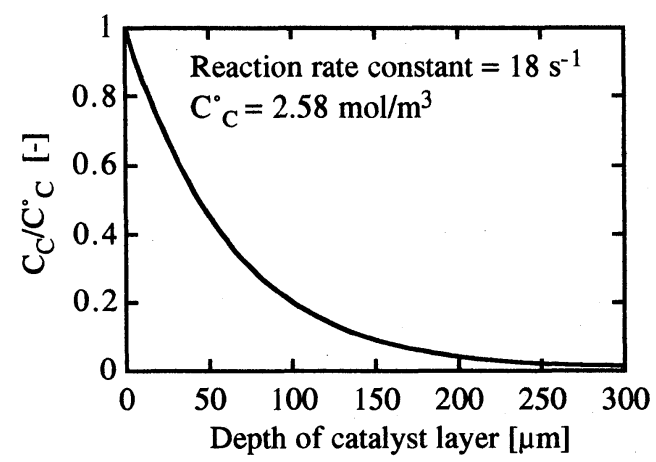

Fig. 5 Relationship between depth of catalyst layer and concentration ratio of cyclohexane.

いる。膜厚が厚くなるにしたがい触媒有効係数が小さく なることが示された。

図 5 には触媒層深さ方向のシクロヘキサン濃度変化を 式 (6) から計算した結果を示している。触媒層の深さ方 向でシクロヘキサン濃度は減少し, 触媒層の厚い触媒で は反応ガスの触媒層への拡散が律速になっていることを 示している。

\section{4 活性の向上}

触媒首が厚くなるにしたがってみかけ面積あたりの反 応速度は向上する。このときの最大反応速度は式 (10) か ら以下のようになる。

$$
L \rightarrow \infty, r_{s} \rightarrow C^{\circ}{ }_{C} \cdot \sqrt{D \times k}
$$

このように最大反応速度は有効拡散係数と反応速度定数 によって決定される。

\section{4. 1 反応速度定数之活性}

図 6 には各反応速度定数における反応速度の変化を示 したあのである。有効拡散係数は一定とした。反応速度 定数の增加に伴い反応速度は上昇し触媒層が薄い場合に はこの傾向が顕著となった。高活性触媒においては膜厚 を厚くする必要がないことを示している。反応速度定数

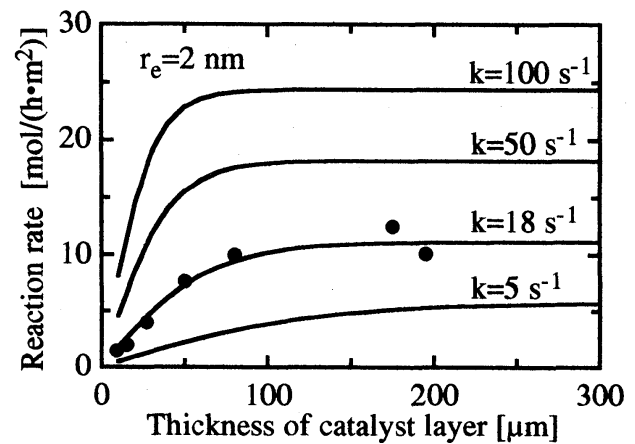

Fig. 6 Effect of reaction rate constant $k$ on the reaction rate with thickness of the catalyst layer.

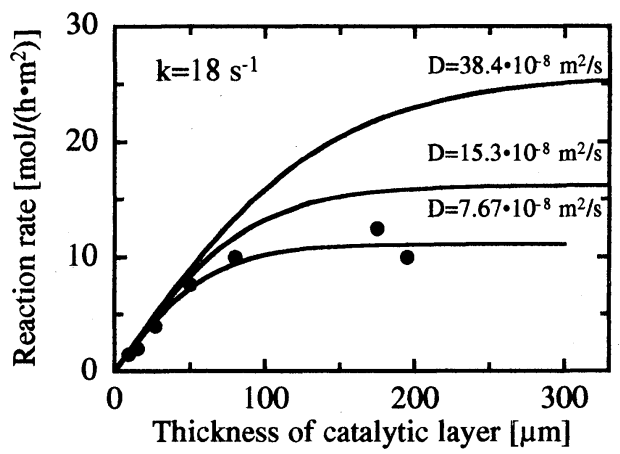

Fig. 7 Reaction rate changes with catalyst thickness.

を向上するためには以下のことが考えられる。

1) 白金担持量と分散度の向上

2 ）白金に変わる活性の高い触媒の開発

本触媒の白金担持量はアルミナあたり $7 \sim 11 \mathrm{wt} \%$, 分散度は 0.5 とともに高い。したがってこれ以上反応速 度を上げるためには，触媒担持方法を検討するか，更に 活性の高い触媒種を探索する必要があると思われる。

\section{4. 2 有効拡散係数之活性}

図 7 には各拡散係数における反応速度の変化を計算し たものを示している。反応速度定数は実験值と同じとし た。反応速度は拡散係数の向上に伴い増加した。

陽極酸化では平均細孔径 $50 \mathrm{~nm}$ のマクロポアが生成し ているが ${ }^{6)}$, 熱水処理によりアルミナ首の水和, 封孔と 白金の担持処理を行った後に焼成することでアルミナ層 の細孔径が $2 \mathrm{~nm}$ まで減少する。寺井らはこの封孔処理 条件を検討することで $50 \mathrm{~nm}$ から $2 \mathrm{~nm}$ までの間で二元 細孔構造を持つ触媒担体の調製法を提案している ${ }^{6)}$ 。

今後は触媒有効係数の観点から反応にあわせた触媒担 体構造を設計し，陽極酸化，熱水処理条件を変化させる ことによって所望の触媒を調製することが可能になると 思われる。 


\section{5. 結言}

本報では陽極酸化，熱水処理により調製したプレート 状触媒の触媒有効係数を実験により求めた。

(1) シクロヘキサン脱水素反応において見かけ表面積あ たりの反応速度は膜厚に伴い向上したが触媒層厚み 150 $\mu \mathrm{m}$ 以上で限界值を示した。

（2）プレート触媒の触媒有効係数の式より実験結果を整 理し触媒有効係数を求めた。触媒層が十分に厚い場合に 最大反応速度を示し, その反応速度は反応速度定数と有 効拡散係数で計算された。

（3）反応速度は触媒種の選定による反応速度定数の向上, または触媒担体の細孔構造を制御することで更に改善さ れる。陽極酸化, 熱水処理条件の検討により反応に適し た触媒担体の設計が可能になることが示唆された。

\section{謝 辞}

本研究は平成 7 年度文部省科学研究費補助金エネルギー 重点領域研究の研究補助を受けて行われたあのである。 ここに感謝の意を表す。

(Received January 17, 1996 ; Accepted May 20, 1996)

\section{《使用記号》}

$C_{C} ;$ シクロヘキサン濃度
$D \quad ;$ 有効拡散係数
$D_{N} ;$ 細孔内拡散係数
$k \quad ;$ 反応速度定数
$l \quad ;$ 触媒層深さ
$L \quad ;$ 触媒層厚み

$\left[\mathrm{mol} / \mathrm{m}^{3}\right]$

$\left[\mathrm{m}^{2} / \mathrm{s}\right]$

$\left[\mathrm{m}^{2} / \mathrm{s}\right]$

$\left[\mathrm{s}^{-1}\right]$

$[\mu \mathrm{m}]$

$[\mu \mathrm{m}]$

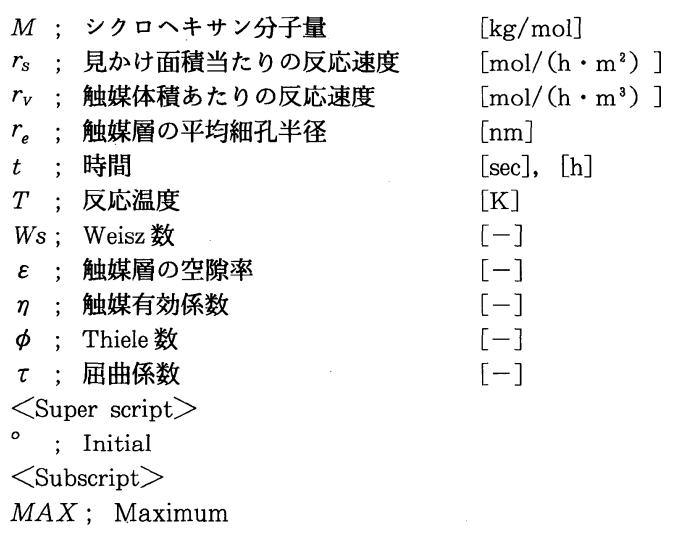

\section{文献}

1) D. Dollimore, G. R. Heal ; J. Appl. Chem., 14, 3, 109 (1964)

2) M. F. L. Johnson and W. E. Stewart; $J$ of Catal., 4, 248 (1965)

3) 村田 究, 山本協子, 亀山秀雄 ; 化学工学論文集, 19, 1, 41 (1993)

4) 村田 究, 山本協子, 亀山秀雄 ; 化学工学論文集, 19, 5, 849 (1993)

5 ）村田 究，亀山秀雄；表面技術，47，173（1996）

6) 寺井 聡, 村田 究, 山本協子, 亀山秀雄; 化学工学論文 集, 21，6，1069 (1995)

7 ）参照触媒委員会 ; 触媒, 31，317（1989）

8 ) C. N. Satterfield; Heterogeneous Catalysis in Industrial Practice (McGraw-Hill, 1991)

9) P. B. Weisz ; Z. Phys. Chem. Neue. Folge, 11, 1 (1957) 